\title{
Forstyrrelser i hjernen ved migrene
}

\author{
Migrenepasientene har mer langsom hjerneaktivitet enn friske kontroll- \\ personer. Funnene viser at hjernebarken hos migrenepasienter er \\ påvirket av sykdommen selv når pasientene ikke har anfall.
}

Marte Helene Bjørk har ved hjelp av EEG målt hjernebølgene hos 41 migrenepasienter og 32 friske kontrollpersoner på flere ulike dager, i hvile og under stimulering med blinkende lys.

- Vi fant at migrenepasientene hadde økt thetaaktivitet, altså langsomme hjernebølger, i forhold til kontrollpersonene mellom anfall. 36 timer før anfall var hjernebølgene enda langsommere, med økt

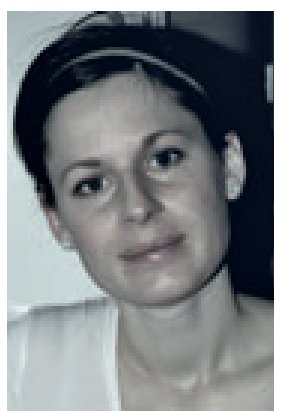

Marte Helene Bjørk. Foto privat deltaaktivitet. Aktiviteten ble også mer asymmetrisk. Selv mer enn 72 timer før anfall var det mer langsomme bølger på den siden av hodet som kom til å utvikle smerter. I perioden like etter anfall var hjerneaktiviteten som ellers mellom anfall, sier Bjørk.
Også følsomhet for anfallstriggere som lyd, lys, lukt og fysisk aktivitet samvarierte med langsommere hjernebølger. Pasienter som hadde hatt sykdommen lenge eller led av lange anfall, hadde langsommere alfaaktivitet, og pasienter med sterke smerter hadde økt deltaaktivitet i alle deler av hjernen.

- Funnene våre indikerer lette funksjonsforstyrrelser i hjernebarken hos migrenepasienter. Endringene av EEG mer enn ett døgn før hodepinen tar til, støtter teorien om at vekslende aktivitetsgrad i hjernebarken kan ha betydning for utviklingen av migreneanfall. Resultatene taler også for at sterke migrenesymptomer kan endre hjerneaktiviteten i lettere grad, sier Bjørk.

\section{Eline Feiring}

eline.feiring@legeforeningen.no

Tidsskriftet

\section{Doktorgradsinformasjon}

Marte Helene Bjørk disputerte for ph.d.graden ved Norges teknisk-naturvitenskapelige universitet 7.1.2011 med avhandlingen Do brain rhythms change before the migraine attack: a longitudinal controlled EEG-study.

\section{Ordforklaringer}

EEG: Elektroencefalografi er en nevrofysiologisk registrering av hjernens elektriske aktivitet ved hjelp av elektroder. Hjernebølgene deles inn i frekvensbånd: delta $10-4$ $\mathrm{Hz})$, theta $(4-8 \mathrm{~Hz})$, alfa $(8-13 \mathrm{~Hz})$ og beta (14-30 Hz). Hos friske ser man hovedsakelig alfaaktivitet i avslappet tilstand med øynene lukket, theta ses under døs og delta under søvn. Beta ses når øynene er åpne og hjernen er aktivisert. Mengden av de ulike frekvensbåndene kan måles objektivt med teknikken kvantitativ EEG (QEEG). I dag brukes QEEG mest i forskningssammenheng.

\section{Seneskader i skulderen}

\author{
Seneskader i skulderen kan påvises med like høy sensitivitet \\ med ultralyd som med MR. Sammensying av skaden gir noe bedre \\ skulderfunksjon enn fysioterapi.
}

Skuldersmerter er et økende problem i dagens samfunn. Plagene er ofte relatert til rupturer i skulderens senemansjett, rotatorcuffen. Rupturene forekommer hovedsakelig hos dem over 40 år. Den naturlige senealdringen, enten alene eller i kombinasjon med traume, er den viktigste utløsende faktoren. Stefan Moosmayer har forsket på diagnostikk og behandling av slike skader.

- Utredning av seneskader skjer vanligvis ved hjelp av MR. Dette er en kostbar metode, som krever henvisning til røntgenavdeling, med påfølgende ventetid. Våre studier viser at ultralyd kan være et alternativ - sammenlikning av preoperative ultralydfunn med funnene fra operasjon viser like gode resultater for påvisning av seneskade som MR gir, sier Moosmayer.

Seneruptur i skulderen kan behandles enten kirurgisk, ved sammensying av senen, eller med fysioterapi. I en randomisert studie med 103 pasienter viste Moosmayer at begge behandlingsmetodene ga bedret skulderfunksjon hos pasientene ett år etter, men på en skala fra 0 til 100 var resultatene etter kirurgi 13 poeng bedre.

Moosmayer fant asymptomatiske senerupturer hos $7,6 \%$ av 420 skulderfriske $\mathrm{i}$ aldersgruppen 50-79 år. Forekomsten økte med alderen. Sammenlikning av asymptomatiske og symptomatiske seneskader viste at hos dem uten plager var det mindre avrivninger og bedre muskulatur enn hos dem som hadde skader som ga plager.

\section{Anne Forus}

anneforus@hotmail.com

Tidsskriftet

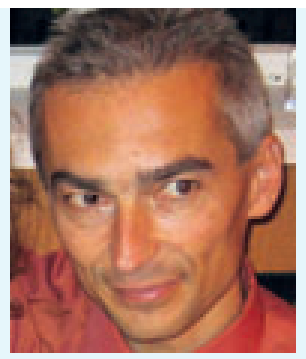

Stefan Moosmayer Foto privat

\section{Doktorgradsinformasjon}

Stefan Moosmayer forsvarte avhandlingen Tears of the rotator cuff - diagnosis, treatment and symptomatic status for ph.d-graden ved Universitetet i Oslo 12.11. 2010.

\section{Ordforklaringer}

Rotatorcuff: Rotatorcuffen består av fire muskler med tilhørende sener (mm. subscapularis, supraspinatus, infraspinatus og teres minor). Musklene har separate utspring på scapula. Mot lateralt løper de sammen med leddkapselen og danner en senemansjett som ligger som en krage rundt caput humeri. Rotatorcuffen bidrar til skulderens rotasjons- og abduksjonsbevegelse og er en viktig stabilisator ved å sentrere caput humeri i leddhulen. 